\title{
Association Analysis of Daun Sang (Johannesteijsmannia altifrons (Rchb. f. \& Zoll) H.E. Moore) with Other Vegetation in Resort Sei Betung, Gunung Leuser National Park
}

\author{
Kansih Sri Hartini $^{1,2}$, Hadi S Alikodra ${ }^{1,3}$, Retno Widhiastuti ${ }^{1,4}$, Herman Mawengkang ${ }^{1,5}$ \\ ${ }^{1}$ Study Program of Natural Resource and Environmental Management, Graduate School, University of Sumatera Utara, Jln. Maas, Medan, \\ Indonesia \\ ${ }^{2}$ Department of Forestry, Faculty of Agriculture, University of Sumatera Utara, Jln. Tri Dharma Ujung No. 1, Medan, Indonesia \\ ${ }^{3}$ Department of Forest Resources Conservation and Ecotourism, Faculty of Forestry, Institute of Agriculture Bogor, Jln. Lingkar \\ Akademik, Kampus IPB Darmaga, Bogor, Indonesia \\ ${ }^{4}$ Department of Biology, Faculty of Mathemathics and Natural Sciences, University of Sumatera Utara, Jln. Bioteknologi No. 1, Medan, \\ Indonesia \\ ${ }^{5}$ Department of Mathematics, Faculty of Mathemathics and Natural Sciences, University of Sumatera Utara, Jln. Bioteknologi No. 1, \\ Medan, Indonesia
}

\section{Email address:}

ksudjarwo@gmail.com (K. S. Hartini), halikodra@gmail.com (H. S. Alikodra), retnows2002@yahoo.com (R. Widhiastuti), mawengkang@usu.ac.id (H. Mawengkang)

\section{To cite this article:}

Kansih Sri Hartini, Hadi S Alikodra, Retno Widhiastuti, Herman Mawengkang. Association Analysis of Daun Sang (Johannesteijsmannia altifrons (Rchb.f. \& Zoll) H.E. Moore) with Other Vegetation in Resort Sei Betung, Gunung Leuser National Park. Agriculture, Forestry and Fisheries. Vol. 3, No. 2, 2014, pp. 108-112. doi: 10.11648/j.aff.20140302.19

\begin{abstract}
The purpose of this research was to analysis an association between Daun Sang and other vegetation in Resort Sei Betung, Gunung Leuser National Park. According to its conservation status, Daun Sang was including on vulnerable categories (VUD2) and its presence was limited, then the action to conserve this species in nature is very important and urgent. This species includes understorey palm, which is need to shade by other species. Purpossive sampling was used with 30 plots, sized $20 \times 20$ meters for Daun Sang and other vegetation at tree stage, $10 \times 10$ meters for other vegetation at pole stage, $5 \times 5$ meter for other vegetation at sapling stage and $2 \times 2$ meter for other vegetation at seedling stage. Analysis of vegetation was used to determine Importance Value Index, Diversity Index, Evennes Index and Richness Index. Then analysis of association was done with an interspesific association analysis, continued with Jaccard Index. The highest Importance Value Indexes for each stage of species were Aglaia edulis for seedlings and saplings, Shorea sp for poles and Shorea dealbata for trees. Diversity Index measured by Shannon Wienner Index was high (3.5-4.02), while the range of Evennes Index was 0.8-0.97 and the range of Species Richness Index was 9.04-14.43. There was an association between Daun Sang and other vegetation on seedlings and poles, which is not strong enough, and no specific association with particular species. This fact is an evidence that if there is forest disturbance, then the population of Daun Sang will be decreased.
\end{abstract}

Keywords: Johannesteijsmannia altifrons, Association, Gunung Leuser National Park

\section{Introduction}

Johannesteijsmannia altifrons is an indigenous species of Sumatera which is not popular such Rafflesia spp and Amorphopalus spp. This species known as Daun Sang, Sang Gajah, Sang Minyak, Daun Payung, and also Salo (Witono, 1998; Mogea, et al, 2001). Its presence is limited, only at Bukit Tiga Puluh National Park and Gunung Leuser
National Park (Mogea, et al, 2001; Qomar, et al, 2006).

According to its conservation status, this species includes on vulnerable categories (VUD2), then the action to conserve this species in nature is very important and urgent. VUD2 indicates that this species will be decreased and will become extinc in the near future, has small population and restricted (less than $100 \mathrm{~km} 2$ ) or the number of population less than five and tends be influenced by people activities 
(Mogea, et al, 2001). Globally, this species includes vulnerable according IUCN Plant Red Data Book 1976 (Lucas and Synge, 1978)

Shade is a characteristic and one of an important factor as a habitat of Daun Sang. It is relevant with Daun Sang as understorey palm. According to that characteristic, there is presumption that Daun Sang has an association with other species in its habitat. The objective of this research was to analysis an association between Daun Sang and other vegetation in Resort Sei Betung, Gunung Leuser National Park.

\section{Methods}

\subsection{Sampling and Study Area}

This research was done at Resort Sei Betung, Gunung Leuser National Park which is known as natural habitat and distribution of Daun Sang. Purpossive sampling applied on the area, consist of 30 single plots with $20 \times 20$ $\mathrm{m}$ on size. Observation for other species on each plot will be distinguished for seedlings $(2 \times 2 \mathrm{~m})$, saplings $(5 \times 5 \mathrm{~m})$, poles $(10 \times 10 \mathrm{~m})$ and trees $(20 \times 20 \mathrm{~m})$, while observation for Daun Sang will be done on $20 \times 20 \mathrm{~m}$.

\subsection{Data Analysis}

Data analysis will be distinguished:1. Vegetation Analysis for other species, including: a. Importance Value Index, b. Shannon Wienner Diversity Index, c. Evenness Index, d. Richness Index, 2. Association Analysis with interspecific pattern.

Association pattern between Daun Sang and other species tested based on presence and absence (binner data) (Ludwig dan Reynolds, 1988). It is determined by Jaccard Index based on pair species method for multispecies. The presence stated 1 and the absence stated 0 . It is completely seen at Table 1.

Table 1. An example presence (1) and absence (0) from $S$ species $(i=1,2,3, \ldots, S)$ on $N$ sample plot $(j=1,2,3, \ldots, N)$.

\begin{tabular}{lllllll}
\hline \multirow{2}{*}{ Species } & \multicolumn{3}{l}{ Sample Plot } & & \multicolumn{2}{c}{ Sum of Species } \\
& $\mathbf{1}$ & $\mathbf{2}$ & $\mathbf{3}$ & $\ldots$ & $\mathbf{N}$ & \\
\hline 1 & 1 & 0 & 1 & & 0 & $\mathrm{n} 1$ \\
2 & 1 & 0 & 1 & & 1 & $\mathrm{n} 2$ \\
3 & 0 & 1 & 0 & & 0 & $\mathrm{n} 3$ \\
$\ldots$ & $\ldots$ & $\ldots$ & $\ldots$ & & $\ldots$ & $\ldots$ \\
S & 0 & 0 & 1 & & 1 & $\mathrm{nS}$ \\
Sum of SP & $\mathrm{T} 1$ & $\mathrm{~T} 2$ & $\mathrm{~T} 3$ & $\ldots$ & $\mathrm{Tn}$ & \\
\hline
\end{tabular}

Interspecific association will be approached with varians ratio (VR) from null association model to test the association difference simultaneously. Steps of analysis, as below (Ludwig dan Reynolds, 1988):

- Create table/matriks data showed presence and absence data as on Table 1.

- $\quad$ State hypothesis. Null hypothesis $\left(\mathrm{H}_{\mathrm{o}}\right)$ state that there are no association between $\mathrm{S}$ species and alternatif hypothesis $\left(\mathrm{H}_{1}\right)$ state that there are an association

\section{between species.}

- Count statistic test. First, count sum of sample varians for $\mathrm{S}$ species presence on sample plots, with a formula:

$$
\sigma_{T}^{2}=\sum_{i=1}^{s} p i(1-p i)
$$

where $\mathrm{pi}=\mathrm{ni} / \mathrm{N}$. And then, estimate varians for sum of all species, as follow:

$$
S_{T}^{2}=\frac{1}{N} \sum_{j=1}^{N}(T j-t)^{2}
$$

where $\mathrm{t}$ is sum of average species per sample plots. Then, Varians Ratio (association Indexes between all species) counted as follow:

$$
V R=S_{T}^{2} / a_{T}^{2}
$$

If $\quad \mathrm{VR}=1$, then there is no association

$\mathrm{VR}>1$, there is positive association

$\mathrm{VR}<1$, there is negative association.

For tested deviation from 1 , then be counted a statistic value $\mathrm{W}$, with a formula:

$$
W=(N)(V R)
$$

If $\mathrm{W}$ lays on $\chi^{2}$ with probability $90 \%$, then the hypothesis that there are no association will be accepted:

$$
X^{2} 0,5 ; N<W<X^{2} 0,95 ; N
$$

\section{Results and Discussions}

\subsection{Importance Value Index}

Importance Value Index (IVI) is a quantitative parameter that can be used to express the degree of acquisition of a particular species in a community. Total species on the observation plots were 116 species, which consists of 23500 individuals seedlings, saplings with 4493 individuals, 260 individuals poles and 203 individuals trees. Table 2, 3, 4 and 5 express ten highest IVI for each stage of life, as below:

Table 2. Table of IVI on seedlings.

\begin{tabular}{ll}
\hline Species & IVI \\
\hline Aglaia edulis & $17.22 \%$ \\
Endiandra sp & $14.16 \%$ \\
Diospyros cauliflora & $11.19 \%$ \\
Eugenia papillosa & $10.95 \%$ \\
Shorea elliptica & $9.04 \%$ \\
Strombosia sp. & $9.04 \%$ \\
Polyalthia glauca & $9.04 \%$ \\
Pterospermum javanicum & $8.67 \%$ \\
Glochidion glomerulatum & $7.96 \%$ \\
\hline
\end{tabular}


Vegetation analysis for seedlings, showed that the highest IVI occupied by Aglaia edulis of $17.22 \%$. Total species found was 52 species. Thus it can be said for $17.22 \%$ of the locations occupied by $A$. edulis, while the rest is controlled by other types. It means that $A$. edulis having a pretty good regeneration in these locations.

On saplings, highest IVI also occupied by Aglaia edulis of $16.14 \%$. Total species recorded reached 85 species. And it turns out $A$. edulis still shows the level of acquisition, although relatively few and smaller than seedlings. It also indicates that competition between species has begun to take place more stringent.

Table 3. Table of IVI on saplings.

\begin{tabular}{ll}
\hline Species & IVI \\
\hline Aglaia edulis & $16.14 \%$ \\
Neocinnamomum sp & $8.29 \%$ \\
Hopea sangal & $7.92 \%$ \\
Diospyros cauliflora & $6.88 \%$ \\
Strombosia sp & $5.85 \%$ \\
Schefflera heterophylla & $5.62 \%$ \\
Eugenia papillosa & $5.62 \%$ \\
Dialium sp & $5.55 \%$ \\
Polyalthia glauca & $5.55 \%$ \\
\hline
\end{tabular}

Table 4. Table of IVI on poles.

\begin{tabular}{ll}
\hline Species & IVI \\
\hline Shorea sp & $14.47 \%$ \\
Vatica cinerea & $14.27 \%$ \\
Pternanda coerulescens & $13.25 \%$ \\
Mallotus subpeltatus & $11.92 \%$ \\
Shorea acuminate & $11.88 \%$ \\
Garcinia dioica & $11.38 \%$ \\
Shorea dealbata & $11.13 \%$ \\
Santiria longifolia & $9.11 \%$ \\
Hopea sangal & $7.95 \%$ \\
\hline
\end{tabular}

At the poles, the highest IVI occupied by Red Meranti (Shorea $\mathrm{sp}$ ) of $14.47 \%$. Total species found was 50 species. While at the trees level, the highest IVI occupied by Curly Damar (Shorea dealbata) of $21.41 \%$ of the total of 77 species.

Table 5. Table of IVI on trees.

\begin{tabular}{ll}
\hline Species & IVI \\
\hline Shorea dealbata & $21.41 \%$ \\
Pternanda coerulescens & $13.36 \%$ \\
Shorea polyandra & $12.45 \%$ \\
Macaranga recurvata & $12.31 \%$ \\
Parashorea lucida & $11.57 \%$ \\
Dipterocarpus retusus & $10.96 \%$ \\
Payena sp & $9.73 \%$ \\
Shorea coriacea & $8.58 \%$ \\
Shorea lepidota & $8.06 \%$ \\
\hline
\end{tabular}

Shorea sp and Shorea dealbata including Dipterocarpaceae. Dipterocarpaceae is a family that is most commonly found in lowland forests. It is relevant with Whitmore's statement (1984), that the canopy of the forest of South-east Asia is dominated by trees from the family Dipterocarpaceae. Family diversity is quite high, but usually species of Dipterocarpaceae including to the opportunity gap species, related to the need for sunlight. Opportunity gap species is a species that requires shade during the germinating until the seedling phase, and after 3 or 4 years old need full light to support growth. If not get the light, over time will be depressed and die. Massey et al. (2006) said that an extremely important phase of the life cycle of these trees is during seedling regenerations. In addition, some dipterocarp also have constraints on seed, ie including recalcitrant seeds, which can not be stored for long periods without deterioration viability (Tompsett \& Krishnapillay, 1998). Dipterocarp seeds also have a fairly high fat content so it is very attractive to wildlife in the forest. That facts are the reason why the less commonly found in dipterocarp seedlings and saplings phase.

\subsection{Shannon Wienner Diversity Index, Evennes Index and Richness Index}

The values of Shannon Wienner index illustrate the diversity within a community. According to Barbour et al. (1987) The Shannon Wienner Diversity Index can be grouped into four, namely: $\mathrm{H}>2$ (low), $2<\mathrm{H}<3$ (moderate), $3<\mathrm{H}<4$ (high), and $\mathrm{H}>4$ (very high). Evenness index which describe the distribution of species, ranges between $0-1$. The more value close to 1 means that equity will be maximum. As for species richness index, the more types, then the value of $\mathrm{R}$ will be even greater. The results can be seen in Figure 1.

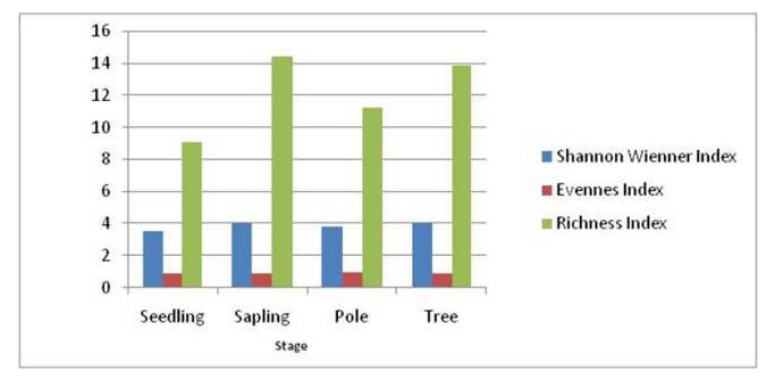

Fig 1. Shannon Wienner Index, Evennes Index and Richness Index.

Based on the analysis results, Resort Sei Betung has a high species diversity, both for seedlings, saplings, poles and trees . It is seen from Shannon Wienner Index value, ranges from 3.5 to 4.02 . It can also be seen from many different species are found, covering 116 species. Shannon Wienner index is fairly high, also indicates the stability of forest vegetation communities, the higher the value the more stable. Seen from evenness, all have almost equal distribution, characterized by the value of the index whose value is between 0.88 to 0.97 or close to 1 . Can be indicated also from IVI, that nobody really absolutely dominate the study site. The highest IVI values only ranged from 14.47 to $21.41 \%$. Species richness were found to be quite high with an index value of 9.04 to 14.43 . The higher the index value of species richness, indicating the higher species richness in the vegetation community 


\subsection{Interspecific Association}

Population interaction occurs in natural at the community and may soon be known and studied, at least qualitatively, although in a very complex community. For a certain type, this type of interaction can change under different circumstances during the stages in a row in his lifetime. Thus, the two species can exhibit parasitism at a time, while the other komensalisme truly neutral and at other times again (Odum, 1993). To see the interaction between all the species found with Daun Sang, calculation of interspecific associations (multispecies) were used. The results of the calculation of interspecific associations (multispecies) can be seen from the value of VR and W. Then the value will be determined by Jaccard Index. VR and $\mathrm{W}$ values can be seen in Table 6 .

Table 6. The value of $V R$ and $W$ on seedlings, saplings, poles and trees.

\begin{tabular}{cccccc}
\hline No. & Stage & VR & Meaning & W & Meaning \\
\hline 1. & Seedling & 3,57 & Association + & 107,04 & $\begin{array}{c}\text { Association } \\
\text { No }\end{array}$ \\
2. & Sapling & 1,23 & Association + & 37,01 & $\begin{array}{c}\text { association } \\
\text { 3. }\end{array}$ \\
Pole & 0,5 & Association - & 15,12 & $\begin{array}{c}\text { Association } \\
\text { No }\end{array}$ \\
4. & Tree & 0,85 & Association - & 25,54 & association \\
\hline
\end{tabular}

Remarks : VR= Varians Ratio $\mathrm{W}=$ Deviation Value VR of 1

Based on Table 6. VR values for seedlings and saplings are greater than 1, then there is a positive association, whereas for pole and tree lesser than 1, then there are a negative association. After calculating the value followed by $\mathrm{W}$, it is known that on seedlings, the value of $\mathrm{W}$ is above the interval $\chi 2$ at the level of $5 \%$ and $\mathrm{N}=52$. It may therefore be concluded happen association between Daun Sang with other species, and then proceed with the calculation of Jaccard Index. Jaccard index between Daun Sang with other species, can be seen in Figure 2, just for 8 highest value. The highest associations indicated by the association between Daun Sang with Endiandra sp, which has a value of 0.43 Jaccard index. This value is low, still below 0.48 according to Kurniawan et al. (2008) which indicates low association.

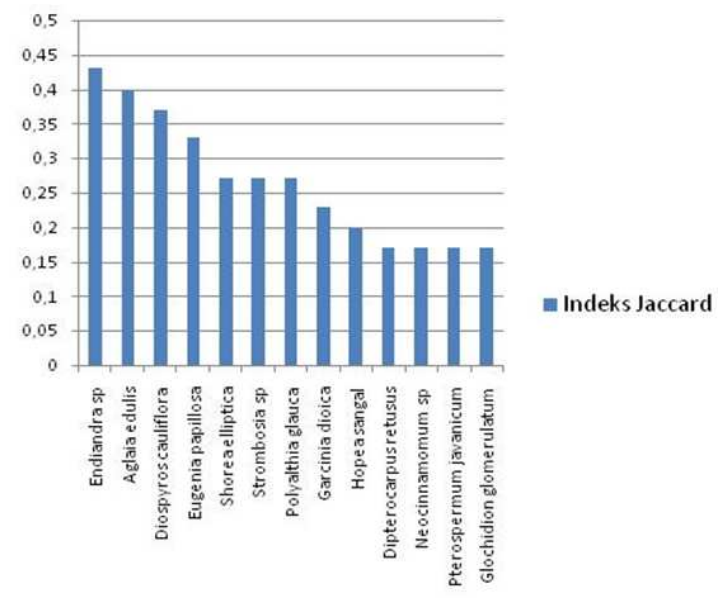

Fig 2. Jaccard Index of seedlings.
On saplings and trees, after calculating the value followed by $\mathrm{W}$, then the value falls within an interval of $\chi^{2}$ at the level of $5 \%$ and $\mathrm{N}=85$ to $\mathrm{N}=77$ and the stakes for trees. While at the level of the pole, the value of $\mathrm{W}$ is under the interval $\chi^{2}$ at the level of $5 \%$ and $\mathrm{N}=50$. Because VR are lesser than 1 , then the associated negative. Then proceed by calculating the Jaccard index between Daun Sang with other species, which can be seen in Figure 3 just for two highest value. The highest associations indicated by the association between Daun Sang with Vatica cinerea, Shorea acuminata, Shorea dealbata, Garcinia dioica, Shorea sp and Pternanda coerulescens having Jaccard index value of 0.10 . This value is very low, less than 0.22 according to Kurniawan et al. (2008) and showed very low associations.

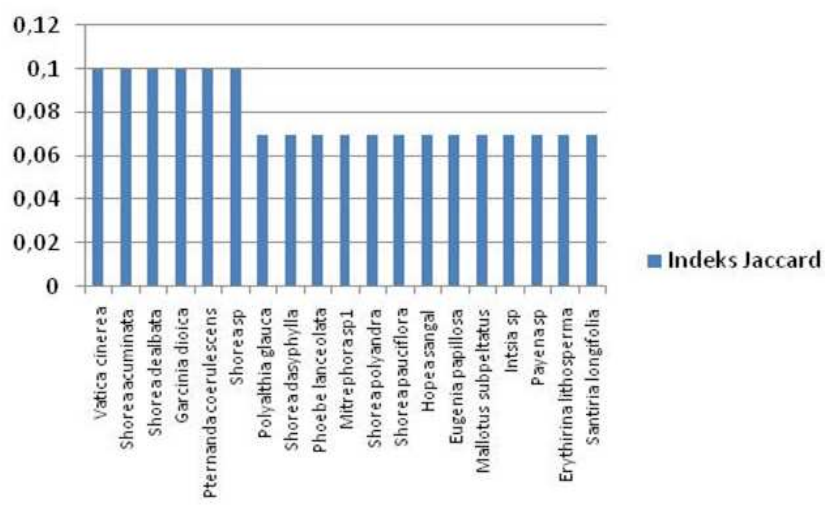

Fig 3. Jaccard Index of poles.

\section{Conclusion}

The highest Importance Value Indexes for each stage of species were Aglaia edulis for seedling and sapling, Shorea sp for pole and Shorea dealbata for tree. Diversity Index measured by Shannon Wienner Index was high (3.5-4.02), while the range of Evennes Index was 0.8-0.97 and the range of Richness Index was 9.04-14.43. There was an association between Daun Sang and other vegetation on seedling and pole, which is not strong enough, and no specific association with particular species.

\section{References}

[1] Witono, J.R. Palm Collection of Bogor Botanical Garden Vol. I No. 1. Unit Development Center Botanical Garden. Indonesian Institute of Sciences. 1998.

[2] Mogea, J.P., Gandawidjaja, D., Wiriadinata, H., Nasution, R. E. dan Irawati. Indonesian Endangered Plant. Edited by Kartikasari, S.N. Center for Biological Research and Development. Bogor. 2001.

[3] Qomar, N., Setyawatiningsih, Rr. S. C. dan Hamzah, Z. Characteristic of Mikro Habitat Salo (Johannesteijsmannia altifrons) around Bukit Tigapuluh National Park, Kabupaten Indragiri Hulu Provinsi Riau. Jurnal Natur Indonesia 8 (2): 100-104. ISSN 1410-9379. 2006. 
112 Kansih Sri Hartini et al.: Association Analysis of Daun Sang (Johannesteijsmannia altifrons (Rchb.f. \& Zoll) H.E. Moore) with Other Vegetation in Resort Sei Betung, Gunung Leuser National Park

[4] Lucas, G., dan Synge, H. The IUCN plant red data book: comprising red data sheets on 250 selected plants threatened on a world scale. International Union for Conservation of Nature and Natural Resources. Threatened Plants Committee. p: 397. 1978.

[5] Ludwig, J. A. dan Reynolds, J. F. Statistical Ecology: a primer on methods and computing. A Willey-Interscience Publication. John Willey \& Sons Inc. USA. 1988.

[6] Whitmore, T.C. Tropical Forest at The Far East 2nd Edition. Oxford: Clarendon. 1984.

[7] Massey, S.E., Massey, K., Press, M.C. and Hartley, S.E. Neigbourhood composition determines growth, architecture and herbivory in tropical rainforest tree seedlings. Journal of Ecology 94: 646-655. 2006.

[8] Tompsett P.B and Krishnapillay, B. Seed Handling (A Review of Dipterocarps: Taxonomy, ecology and silviculture). Editors: Appanah, S \& Turnbull, J.M. Center for International Forestry Research. Bogor. 1998.
[9] Barbour, M.G., Burk, J.H. dan Pitts, W.D. Terrestrial Plant Ecology. Chapter 9: Method of sampling the plant community. Menlo Park, CA: Benjamin/Cummings Publishing Co. 1987.

[10] Odum, E.P. Fundamentals of Ecology. Third Edition. Translated by: Samingan, T., Srigandono, B. Gadjah Mada University Press. Yogyakarta. 1993.

[11] Kurniawan, A., Undaharta, N.K.E., Pendit, I.M.R. Association of dominated tree species in lowland tropical forest of Tangkoko Nature Reserve, Bitung, North Sulawesi. Biodiversitas Vol 9. No. 3, pp 199-203. 2008.

[12] Hartini, K.S. Daun Sang Conservation Model (Johannesteijsmannia altifrons (Rchb.f. \& Zoll.) H.E. Moore) at Resort Sei Betung, Gunung Leuser National Park. Dissertation. Graduate School. University of Sumatera Utara 2013. 